\title{
Molecularly Imprinted Polymer-Based Microfluidic Systems for Point-of-Care Applications
}

\author{
Yeşeren Saylan $(1)$ and Adil Denizli * \\ Department of Chemistry, Hacettepe University, Ankara 06800, Turkey; yeseren@hacettepe.edu.tr \\ * Correspondence: denizli@hacettepe.edu.tr; Tel.: +90-312-297-7963
}

Received: 27 September 2019; Accepted: 8 November 2019; Published: 11 November 2019

\begin{abstract}
Fast progress has been witnessed in the field of microfluidic systems and allowed outstanding approaches to portable, disposable, low-cost, and easy-to-operate platforms especially for monitoring health status and point-of-care applications. For this purpose, molecularly imprinted polymer (MIP)-based microfluidics systems can be synthesized using desired templates to create specific and selective cavities for interaction. This technique guarantees a wide range of versatility to imprint diverse sets of biomolecules with different structures, sizes, and physical and chemical features. Owing to their physical and chemical robustness, cost-friendliness, high stability, and reusability, MIP-based microfluidics systems have become very attractive modalities. This review is structured according to the principles of MIPs and microfluidic systems, the integration of MIPs with microfluidic systems, the latest strategies and uses for point-of-care applications and, finally, conclusions and future perspectives.
\end{abstract}

Keywords: microfluidic; molecular imprinting; point-of-care; polymers

\section{Introduction}

Selective and sensitive biomolecule detection plays an important role in many systems [1]. Although natural recognition elements have high affinity to their target molecules, they have limited application due to sensitive features, including low durability and stability at high pressure and temperature in different media [2]. In recent times, under the category of supramolecular chemistry, the molecular imprinting technique has been offered as a means to overcome most of these drawbacks. This technique was first reported in the 1970s [3] and has since been adopted by many scientists, as evidenced by the increase in studies from all over the world. It is generally and principally based on the selective recognition of template molecules [4]. Molecularly imprinted polymers (MIPs) can also be synthesized using various functional monomers, template molecules, crosslinkers, initiators, and solvent compositions [5-9]. The MIPs have also a lot of benefits, such as easy preparation, cost-friendliness, and high stability, selectivity, and affinity toward the template molecules. The quality of the MIPs can be changed with different combinations of experimental conditions and interaction mechanisms [10-12].

Microfluidics is the science and technology of systems that process small amounts of fluids $\left(10^{-9}-10^{-18} \mathrm{~L}\right)$, employing channels with dimensions of tens to hundreds of micrometers [13]. They have a huge potential to impact different subject areas, from biological analysis to information technology. Microfluidic systems possess a number of useful advantages, such as the use small of quantities of samples and detection with high resolution and sensitivity, short analysis time, low cost, and small footprints $[14,15]$. Microfluidic systems are also small in size and the properties of fluids in microchannels are less visible. They especially present fundamentally novel abilities in the control of biomolecule concentrations [16]. In many ways, the basic properties of microfluidic systems allow for their natural adaption information point-of-care diagnostics devices, such as 
for diagnostic tests performed near the patient without the need for a clinical laboratory and allowing for the low consumption of reagents and sample, miniaturization of devices, and fast turnaround time for analysis $[17,18]$. Due to the need to detect important biomolecules, the applications of molecular screening in diagnostics, as well as in food and environmental fields are growing fast [19]. Biomolecule detection in several samples is frequently carried out in laboratories employing commercial techniques, including immunoassays and chromatographic techniques that are laborious, time-consuming, expensive, and require rigorous conditions and specialized staff [20]. Thus, the interest and need for the fabrication of cheaper, faster, user-friendly, and reusable detection platforms has been increasing. The recognition elements can be bound to the biomolecules that are immobilized on a signal transducer in these platforms. The binding interactions can be translated by readout methods into a concentration-dependent signal [21].

In this review, the fundamentals of MIPs and microfluidic systems, the integration of MIPs with microfluidic systems, and their recent uses in the applications of point-of-care applications are extensively discussed. The conclusions and future perspectives are summarized at the end of the review.

\section{Fundamentals of Molecularly Imprinted Polymers (MIPs)}

The template molecules, functional monomers, crosslinkers, initiators, and solvents are essential and key elements for the polymerization of MIPs. At first, the template molecule interacts with the functional monomer to acquire pre-complex structures and the pre-complex is then polymerized in the presence of a crosslinker to obtain a polymeric matrix [22]. After template molecule removal, template-specific binding cavities are formed in the polymeric matrix and the MIP is ready for interaction (Figure 1).
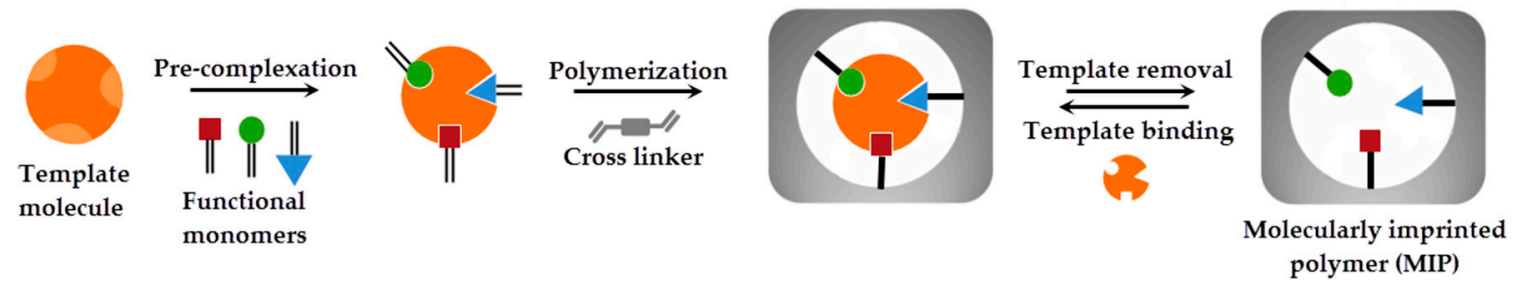

Figure 1. The steps of the molecularly imprinted polymer (MIP) preparation.

Template molecule selection is the most significant step in MIP preparation. In this step, crosslinking functional monomers are surrounded by the selected template molecule with specific interactions. After the polymerization, the template molecule is removed by suitable eluents from the polymeric matrix to obtain MIPs that have specific template molecule-binding sites [23,24]. The other important part is functional monomer selection, which is a crucial step to prepare the optimum combination of template molecule and functional monomer. On the other hand, it only increases the complexity of the chemical environment and may end up in disruptions [25,26]. Additionally, the crosslinker makes the polymeric matrix chain bind to another chain. It plays crucial functions to produce a rigid polymeric matrix and also comprises recognition groups [27]. Another important element is the initiator, that effects polymer production by linking a large number of monomers. The initiator should be selected due to the polymerization type and template molecule [28]. The last element is a solvent that makes a more expanded polymeric matrix chain, or the chains stay close to each other. It has a vital role as a porogen maker that checks the morphology and porosity of the polymeric matrix [29]. Thus, MIPs can be synthesized by using functional monomers and template molecules in the presence of appropriate crosslinkers, initiators, and solvents. The template-specific cavities are obtained with a certain size, shape, and chemical and physical effectivity at the end of the polymerization [30]. In the literature, there are several studies about new recognition elements such as MIPs, phages, aptamers, and affibodies. They are preferred to be use for polymerization instead 
of classical recognition elements (enzymes, antibodies, nucleic acids, and whole cells) due to their ability to mimic natural recognition entities and providing a versatile platform to achieve the desirable functionality for various point-of-care applications [31-33].

\section{Principle of Microfluidic Systems}

The principle of microfluidic systems depends on the science of studying the behavior of the flow of fluid through and around structures at the microscale level. Microfluidic systems have to test themselves against the classical systems and provide opportunities such as high sensitivity, low cost, short time, and lower consumption of laboratory space. In addition, scaling effects guide phenomena and allow new applications that are not accessible to classical platforms, including a high grade of parallelization, laminar flow with liquid gradients down to single-cell-length scales, high-speed serial processing, and structures the size of a cell. The amount of reagent consumption can be minimized significantly by scaling down the assay volume and also by reducing the footprint of each test. With decreasing length scales, capillary forces become increasingly dominant over volume forces and enable passive liquid actuation used in the capillary test strips. Another effect is the onset of laminar flow at low Reynolds numbers in microchannels that allows the creation of well-defined and stable liquid-liquid interfaces down to cellular dimensions [34-37]. As depicted in Figure 2, this microfluidic system technology has a long history from research to diagnostics used in hospitals. The evolution started at around the 1950s, and still continues to grow to supply certain needs [38].

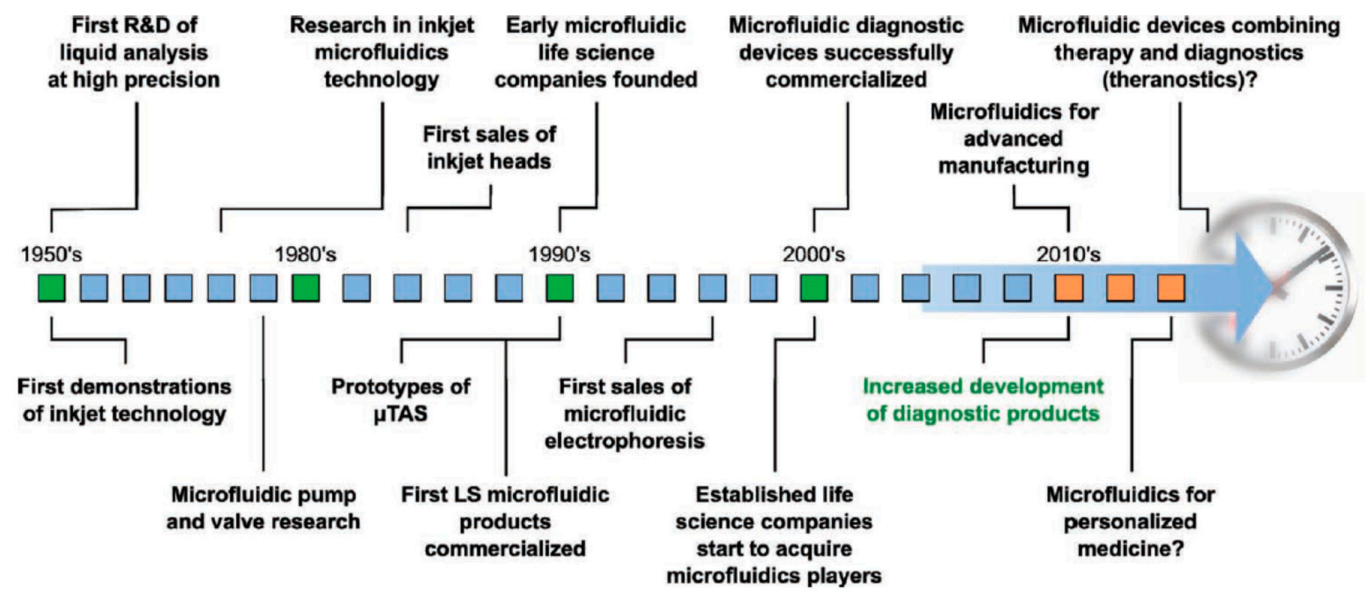

Figure 2. The timeline of the microfluidic technology evolution. Republished with permission from Gervais et al. [38].

\section{Integrations of MIPs with Microfluidic Systems}

Microfluidic systems and MIPs have been integrated and extensively utilized in point-of-care applications, thanks to significant advantages such as the need for low sample volume, integrality selectivity, and sensitivity. Practicality gains attention in the generation of integrated systems that are self-contained, automated, and rapid [39,40]. Furthermore, microfluidic systems have been frequently used for the nanoparticle and nanofilm immobilization. These nanomaterials have exclusively been used in MIP-based microfluidic systems for different applications, such as quartz crystal microbalances, surface plasmon resonance, and colorimetric and fluorescence sensors [41,42].

\section{Latest Strategies of MIP-Based Microfluidic Systems}

Recently, several technologies of molecular imprinting techniques have earned prompt development according to the continuous use and improvement in traditional polymerization and modification techniques. Moreover, diversified MIP-based microfluidic systems with excellent performances have been prepared for exciting and universal applications [43]. 


\subsection{Polymers}

MIPs have shown high performance in several applications, generally exceeding the conventional methods and providing a more cost-effective approach [44]. For instance, Ali et al. prepared MIP-based hydrogels for the release of ketotifen fumarate that were employed in therapeutic contact lenses. They carried out in vitro drug release studies from contact lenses within a microfluidic system that simulated tear volume and tear composition of an eye. As shown in Figure 3, the MIP-based hydrogel was placed in the microfluidic chamber between the four posts and drug release was quantified within artificial lacrimal fluid flow rates. They reported that this contact lens has a suspended release of the drug compared to less functionalized systems. In addition, this MIP-based contact lens showed Fickian release kinetics, with diffusion coefficients ranging from $4.04 \times 10^{-9}$ to $5.57 \times 10^{-10} \mathrm{~cm}^{2} / \mathrm{s}$ [45].

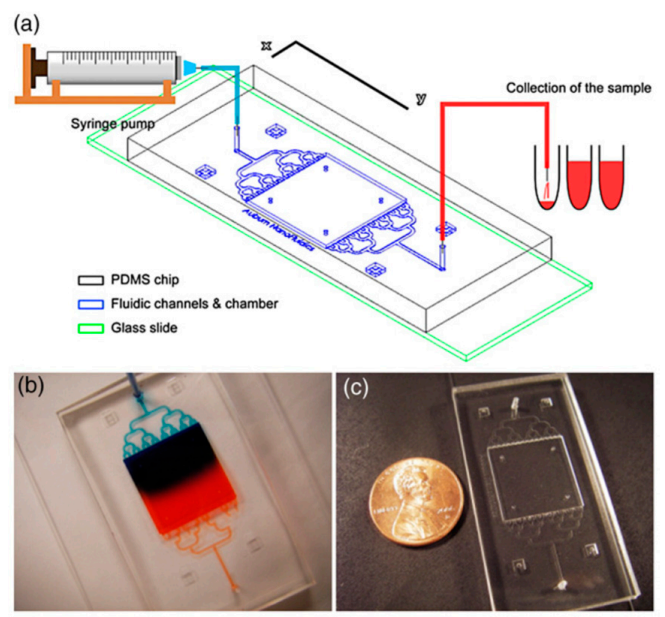

Figure 3. The microfluidic system design. Republished with permission from Ali et al. [45].

Shiraki et al. also synthesized a MIP-based hydrogel with a microfluidic system to detect bisphenol A that has a high ability to interrupt the endocrine system. They used cyclodextrin as a ligand and polymerized using a fluorescence microscope. They showed that this MIP-based hydrogel had an ultra-fast shrinkage in response to bisphenol A and, also, that the flow rate of the microchannel was adjusted by the shrinking of the hydrogels [46].

Takimoto et al. prepared submillimeter-sized MIP-based microgels using polymerization of water-soluble monomers with a photoinitiator in water-in-oil droplets produced by the microchannel (Figure 4). After the optimization of suitable surfactants, surfactant concentration, and flow rate selection, the microgel size was managed by the oil phase flow rate for human serum albumin recognition. Furthermore, they reported the submillimeter-sized MIP-based microgels exhibited a high selective and affinity binding toward human serum albumin [47].

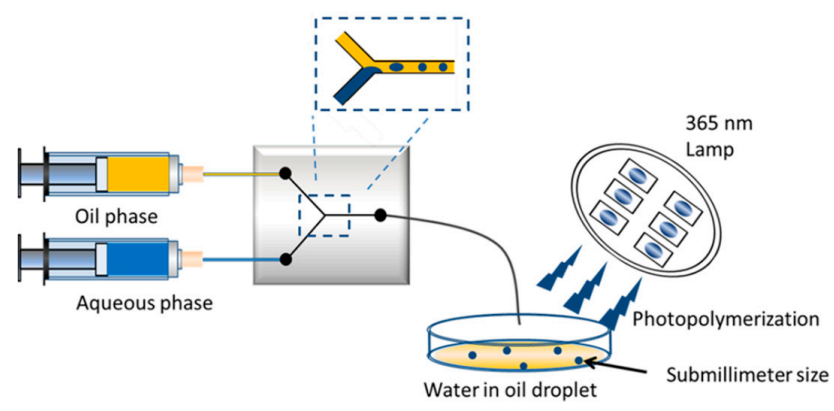

Figure 4. The submillimeter sized MIP-based microgels preparation. Republished with permission from Takimoto et al. [47]. 
Ren et al. covered glass with bacteria that was pushed into another glass covered with polydimethylsiloxane. The polydimethylsiloxane was hardened, and the bacteria were eluted to produce a textured surface whose indentations capture the same type of bacteria when mixture flows over it. They found that the selectivity between the Gram-negative and Gram-positive bacteria groups was stronger than the bacteria in the same group. Furthermore, some selectivity was also detected between the closely related species in the same Gram bacteria groups [48].

Hong et al. presented an immune-like membrane for separation and sensation C-reactive protein in serum samples employing the MIP-based nanocavities. They enhanced the performance of separation by an alignment of the C-reactive protein. They synthesized aligned the MIP-based nanocavities and integrated with microfluidic systems as point-of-care applications (Figure 5). They demonstrated that the adhesion forces of the MIP-based nanocavities on the immuno-like membranes were comparable to the interaction forces between C-reactive protein and antibodies [49].

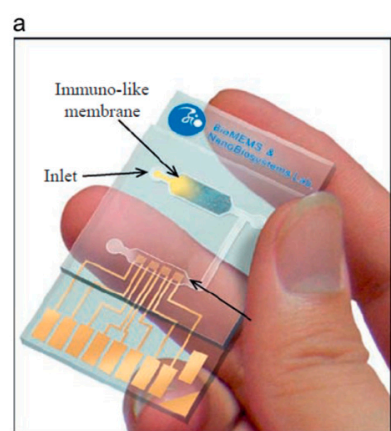

b-2

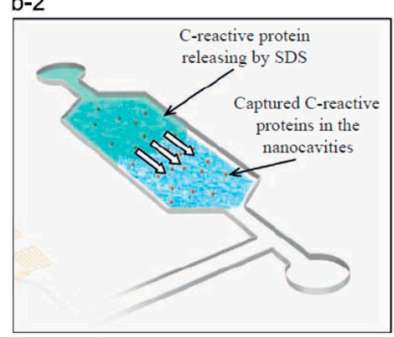

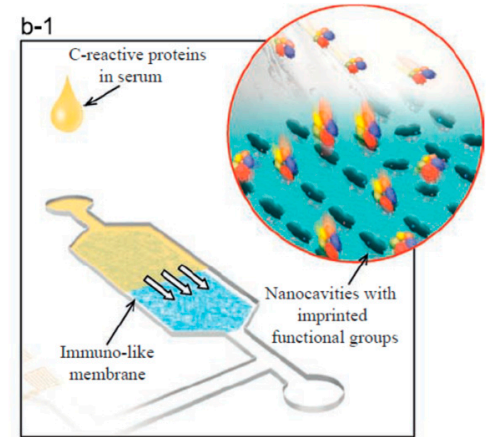

b-3

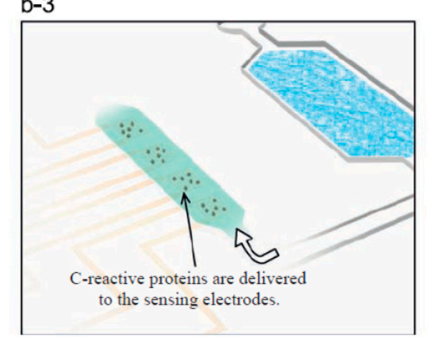

Figure 5. The illustration of the MIP-based nanocavities (immuno-like membrane in microfluidic system (a); loading of serum samples into the microfluidic system and capturing C-reactive protein from serum samples (b-1); loading of SDS and releasing of C-reactive protein from the immuno-like membrane (b-2); delivery of SDS with C-reactive protein to the electrodes (b-3)). Republished with permission from Hong et al. [49].

Kellens et al. demonstrated a microfluidic system in conjunction based on functionalized diamond substrates. They claimed that this strategy was low cost, simple, and efficient for testosterone detection in urine, buffer, and saliva samples. They also adapted this microfluidic system to a sensor using electrochemical impedance spectroscopy and obtained a low limit of detection value $(0.5 \mathrm{nM})$ under a wide range of testosterone concentrations [50].

\subsection{Sensors}

Due to their insufficient lower limits of detection and their lower analytical specificity, as compared to antibodies, the quantification and detection of some clinically relevant biomolecules by MIP-based sensors has been gaining importance and studied extensively in recent years [51]. For example, Harz et al. described a study on an immobilized MIPs with a microfluidic system for fluorescence detection of dansyl-L-phenylalanine. They presented the immobilization of the polymers on quartz surfaces to produce homogenous films and their uses in a spectrofluorometer. As depicted in Figure 6, the excitation and emission lights were represented, with holder, excitation angle, and easy adjustment of position 
at the system also demonstrated. They showed more sensitive detection of dansyl-L-phenylalanine (fifty times) compared to without MIPs [52].

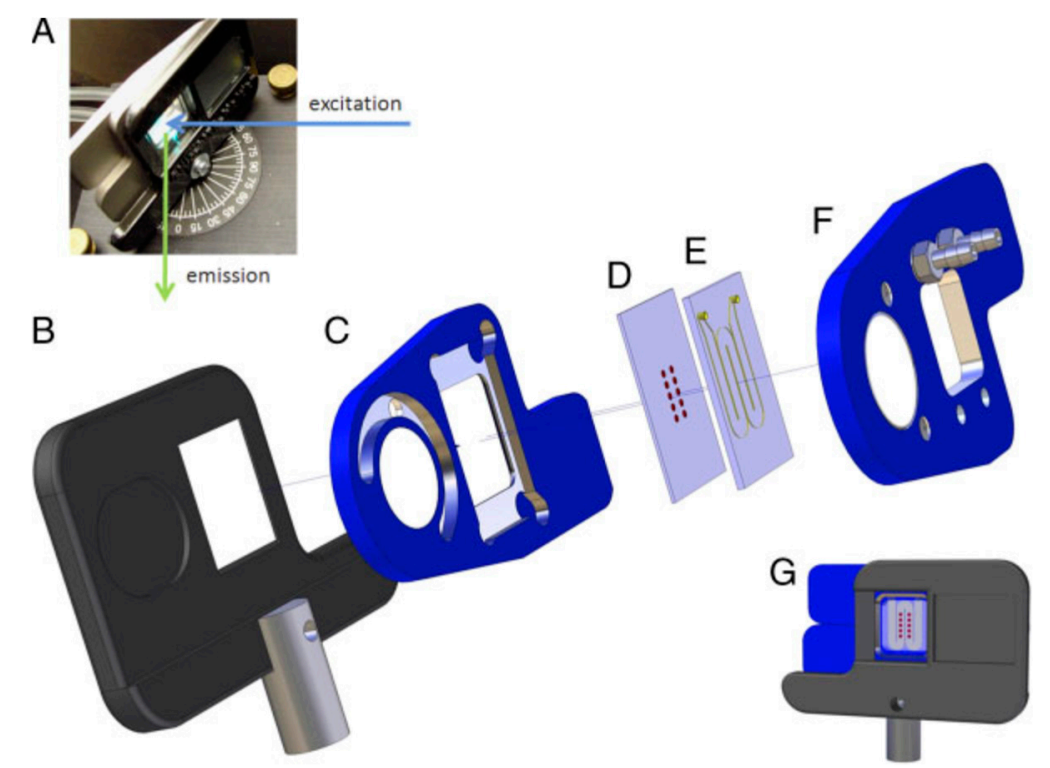

Figure 6. The microfluidic system and holder for fluorescence measurements (excitation and emission light beams in a spectrofluorometer (A); holder for the microfluidic system (B); magnetically connected holder with window (C) and (F); substrate on MIPs (D); microstructured meander for fluid transport (E); arranged setup with all components $(\mathbf{G})$ ). Republished with permission from Thaler et al. [52].

Sharma et al. designed a MIP-based receptor that has cavities to detect an autism biomarker (oxytocin nonapeptide). They deposited this MIP-based receptor by electropolymerization on a gold film electrode in an electrochemical microfluidic system. They performed the kinetic studies in a different biomarker concentration range (from 0.06 to $1 \mathrm{mM}$ ) with a detection limit of $60 \mu \mathrm{M}$. They also carried out sensitivity analysis of the microfluidic system in both synthetic serum and aqueous samples, and reported that this MIP-based microfluidic system was selective to common interferences, including oxytocin analogs and potential metabolites [53].

Liu et al. established an electrochemical detection platform by integrating MIPs with a microfluidic system and utilized this for therapeutic drug detection. They characterized the working electrode via electrochemical impedance spectroscopy and cyclic voltammetry and tested the linearity of the method in the range of $5 \times 10^{-6}$ to $4 \times 10^{-4} \mathrm{M}$. By contrast, the linearity of gate effect was $2 \times 10^{-11}$ to $4 \times 10^{-9}$ $\mathrm{M}$ with a low detection limit $\left(8 \times 10^{-12} \mathrm{M}\right)$ which is suitable for clinical assays. They also applied this to monitor drug concentrations in rabbit plasma over a day [54].

Weng et al. designed a microfluidic system to detect morphine employing the MIP-based electrochemical sensing principle. They integrated a polydimethylsiloxane microchannel, a peristaltic micropump, microvalves, and sensing microelectrodes to prepare a MIP-based microfluidic system for morphine sensing. The morphine samples were transported to the electrode using the automatic peristaltic micropump. They showed that the sensitivity of the MIP-based microfluidic system is $0.3 \mu \mathrm{M}$ in detecting morphine concentrations ranging from 0.01 to $0.2 \mathrm{mM}$ [55].

Hong et al. proposed a handheld analyzer with a disposable system for detection of anesthetic propofol in total intravenous anesthesia with a target controlled in a fusion system for detection in plasma samples. Their system is based on the conduction of MIPs and electrical detection (Figure 7). They employed this for detecting blood propofol concentrations in hospitals to compare with other conventional methods (high-performance liquid chromatography and ion mobility spectrometry). They revealed that the response time of the system was very short $(25 \mathrm{~s})$ and the detection limit was $0.1 \mu \mathrm{g} / \mathrm{mL}$ with a range of $0.1-30 \mu \mathrm{g} / \mathrm{mL}$ [56]. The same research group also presented a disposable microfluidic 
system for optical detection of propofol (Figure 8). They integrated MIPs into the microfluidic system to be used for propofol detection optically at $655 \mathrm{~nm}$ wavelength after the reaction of propofol with color reagent and obtained the limit of detection value as $0.25 \mathrm{ppm}$ in a range from 0.25 to $10 \mathrm{ppm}$ [57].

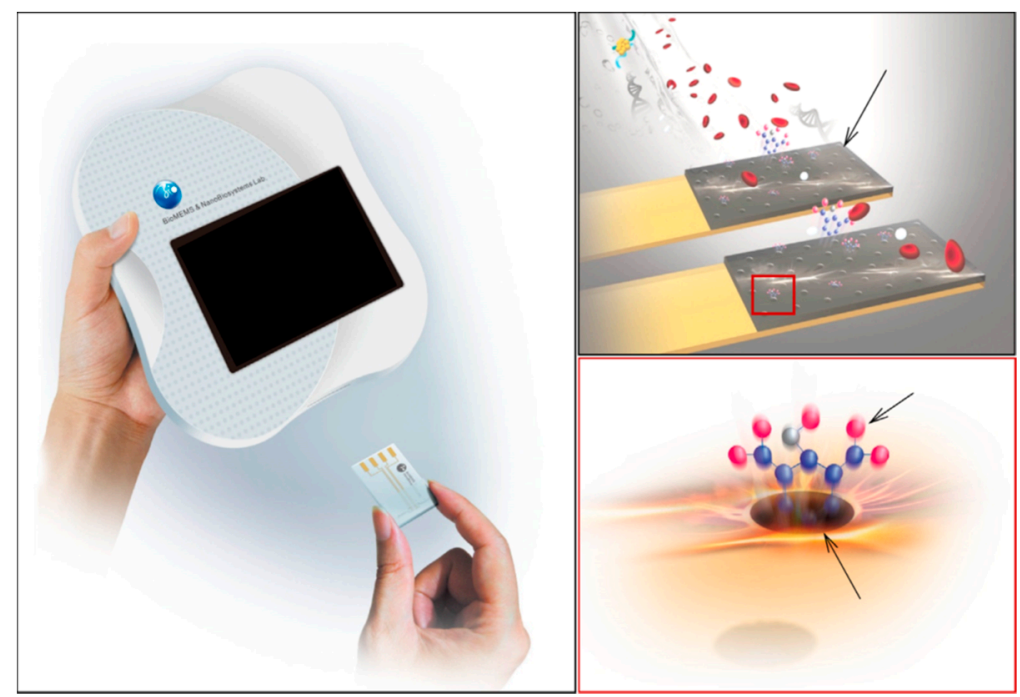

Figure 7. The propofol sensing system. Republished with permission from Hong et al. [56].

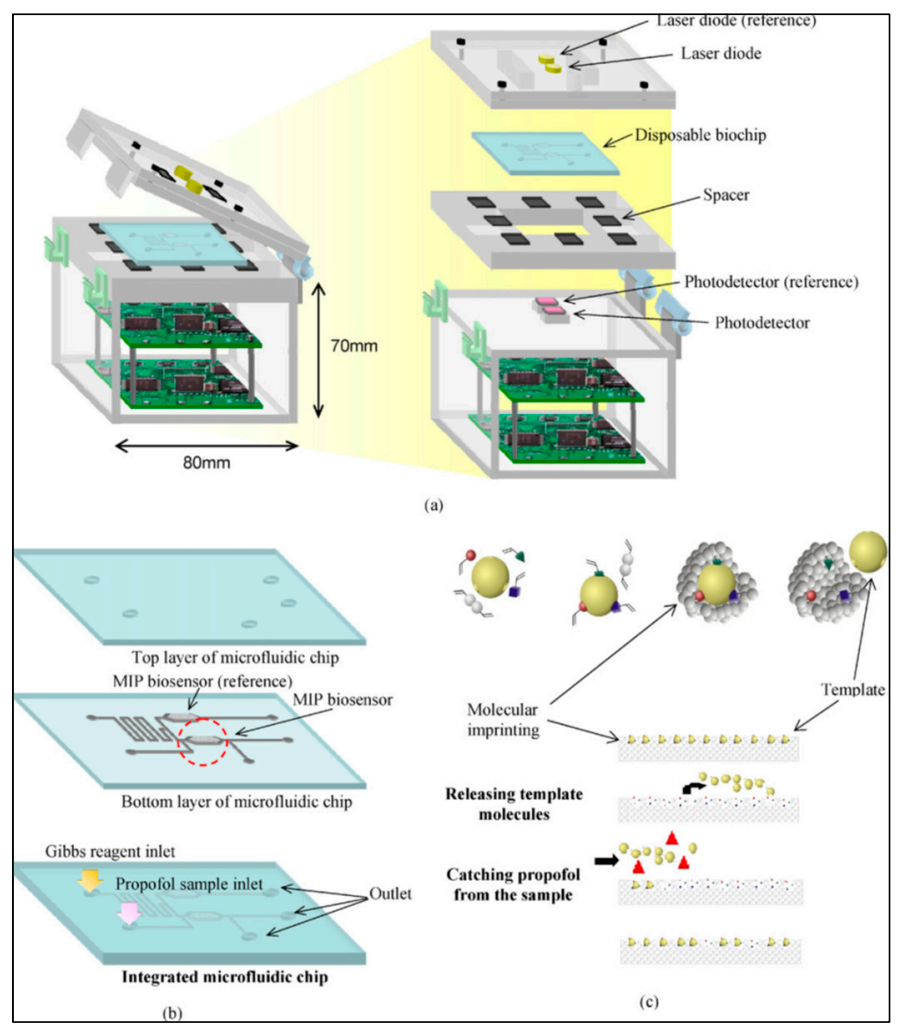

Figure 8. The microfluidic system with MIPs for propofol detection. Republished with permission from Hong et al. [57].

Dejous et al. introduced an electronic nose or tongue for data processing in complex media such as biomarkers in breath or liquid. They exemplified with a versatile acoustic wave transducer that was modified with MIPs to detect adenosine-51-monophosphate. They described the thin film coating and then demonstrated the static measurements with electrical and scanning electron microscopy characterization after each step of the process [58]. 


\subsection{Papers}

The emerging paper-based microfluidics systems show more seductive benefits with more useful components being integrated into a platform in several applications [59-61]. The papers have been adopted as attractive detection platforms due to their incomparable properties, such as low sample consumption and low cost and, also, pump-free transportation [62].

Kong et al. developed a paper-based colorimetric microfluidic system to detect bisphenol A using magnetic nanoparticle peroxidase activity and the MIP-based membrane adsorption capacities. As depicted in Figure 9, this system was fabricated via MIP-based membrane immobilization. They employed the isotherm models of MIP-based membranes to determine the interaction and evaluated maximum adsorption capacity. They found the grey intensity to be comparable for the bisphenol A concentrations in the range of $10-1000 \mathrm{nM}$ with a detection limit of $6.18 \mathrm{nM}$ [63]. The same research group also constructed a paper-based system utilizing multiplate nanoflowers and MIP-based membranes for amino acid detection. They reported this system selectively detected the analytes as well as decreased the electron loss via blocking the reduction reaction between electrons and products. This device showed the detection limits toward two different amino acids to be as low as 9.6 and $24 \mathrm{pM}$. They also pointed out that nanoflowers showed superior signals associated with nanospheres, nanosheets, and nanorod platforms [64].

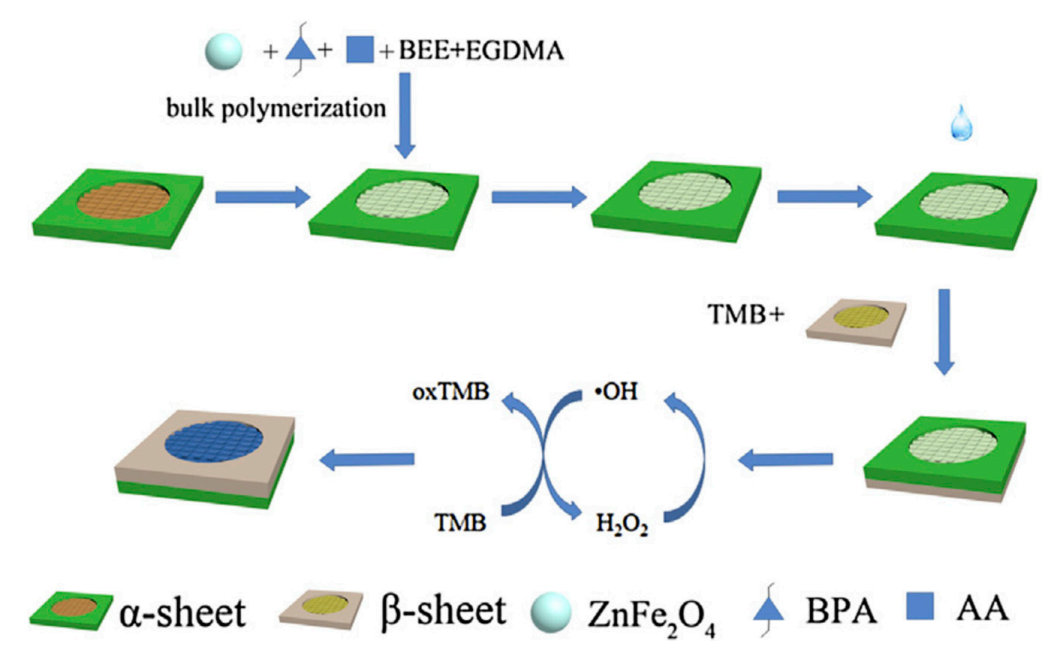

Figure 9. The paper-based colorimetric sensor fabrication steps. Republished with permission from Kong et al. [63].

Li et al. developed an origami paper-based microfluidic system employing quantum dots related to MIPs for the sensitive and selective recognition of phycocyanin. Figure 10 schematically illustrates the structure and the sensing principle of a three-dimensional origami paper-based microfluidic system. This system could realize the liquid phase of quantum dots combined with MIPs being transferred to the solid-phase paper base and achieved easy portability. They reported that their three-dimensional origami paper-based microfluidic system could detect phycocyanin in a dynamic range of $10-50 \mathrm{mg} / \mathrm{L}$ with a limit of detection of $2 \mathrm{mg} / \mathrm{L}$ [65]. The same research group also proposed an origami ion-imprinted microfluidic paper-based system to multiplex detect $\mathrm{Cu}^{2+}$ and $\mathrm{Hg}^{2+}$ ions. They activated the surfaces by grafting with quantum dots and carried out the formation of quantum dots-based ion-imprinted complex that led to fluorescence quenching. They reported that the $\mathrm{Cu}^{2+}$ ion-imprinted fluorescent platform exhibited linearity from 0.11 to $58.0 \mu \mathrm{g} / \mathrm{L}$ with a detection limit of $0.035 \mu \mathrm{g} / \mathrm{L}$ and the $\mathrm{Hg}^{2+}$ ion linear range is $0.26-34.0 \mu \mathrm{g} / \mathrm{L}$ with a detection limit of $0.056 \mu \mathrm{g} / \mathrm{L}$ [66].

Ge et al. also fabricated a paper-based microfluidic system using electropolymerization of MIPs in gold nanoparticle-modified paper. This was prepared through the growth of a gold nanoparticle layer on the surfaces of fibers in the paper working electrode. They developed a microfluidic origami 
system that consisted of an auxiliary pad encompassed by sample tabs to detect amino acid D-glutamic acid in a linear range from 1.2 to $125.0 \mathrm{nM}$ with a low detection limit (0.2 nM) [67].

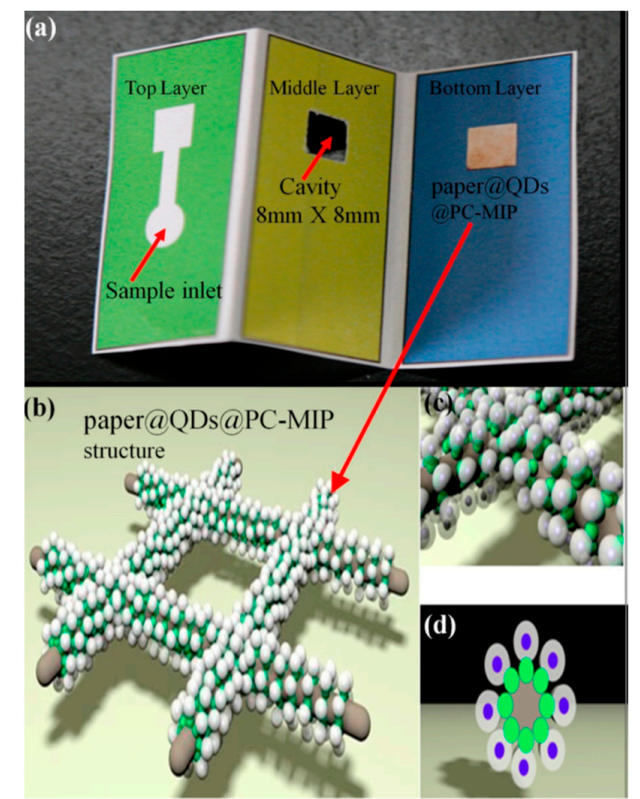

Figure 10. The structure of the origami paper-based microfluidic system. Republished with permission from $\mathrm{Li}$ et al. [65].

\section{Conclusions and Future Perspectives}

During recent years, the health status of people has become a major public concern with interest in disease detection growing all over the world. For example, air pollution possesses a significant threat and causes several diseases, such as oncologic, cardiovascular, neurodegenerative, and also chronic respiratory diseases. Conventional methods applied for diagnosis of these diseases usually comprises invasive and hazardous biopsy, mammography, endoscopy, blood tests, computed tomography, microbial culture tests, magnetic resonance imaging, ultrasonography, positron emission tomography, and/or X-ray imaging of organs. Less or more highly invasive methods not only represent some risks of dangerous adverse side effects, including surgical complications and internal burns, but they frequently dispirit patients from participating in preventive screening procedures. Moreover, conventional methods, despite offering a convenient way to analyze complex samples, also have some disadvantages and limitations. In addition, these methods are not tractable for routine and rapid assays due to the polar nature of biomolecules and certain complex sample pre-treatment before analysis. They also require sample handling and blood collection, with possible contamination and requirement of highly skilled personnel. They are often also time consuming and need expensive and sophisticated instrumentation. Hence, there is still a huge need for the development of proficient detection systems in order to pre-empt this problem in public health. In these circumstances, microfluidic systems are assumed to propose complementary tools to conventional methods, as devices devoted to biomolecules with a fast response time and convenience of usage. Among the systems under development, some aim to achieve high quality and precision of test results for diagnostic purposes and the detection of diseases in their early stages. In addition, MIP-based microfluidic systems offer robust, reusable, and highly selective and sensitive platforms to detect important biomolecules.

This review article aimed to discuss the principle of MIPs and the integration of MIPs with microfluidic systems. The recent studies of MIP-based microfluidic systems were extensively overviewed for different targets in point-of-care applications. They were prepared using different template molecules, functional monomers, crosslinkers, initiators, and solvents. Compared with 
conventional techniques, these MIP-based microfluidic systems have several advantages and show more promising applications for improving human health (Table 1).

Table 1. Summary of the recent MIP-based microfluidic systems.

\begin{tabular}{|c|c|c|c|c|c|}
\hline Material & Target & Advantages & Dynamic Range & Detection Limit & Reference \\
\hline Hydrogel & Ketotifen fumarate & $\begin{array}{l}\text { A potential determination of } \\
\text { physiological release rates, } \\
\text { matching local conditions to } \\
\text { characterize drug delivery } \\
\text { devices }\end{array}$ & $\begin{array}{c}4.04 \times 10^{-9} \text { to } \\
5.57 \times 10^{-10} \mathrm{~cm}^{2} / \mathrm{s}\end{array}$ & - & [45] \\
\hline Hydrogel & Bisphenol A & $\begin{array}{l}\text { An ultra-fast shrinkage in } \\
\text { response, adjusted flow rate } \\
\text { by the shrinking of the } \\
\text { hydrogels }\end{array}$ & $120 \mu \mathrm{g} / \mathrm{mL}$ & - & [46] \\
\hline Microgel & $\begin{array}{l}\text { Human serum } \\
\text { albumin }\end{array}$ & $\begin{array}{l}\text { A high affinity, selectivity and } \\
\text { stability }\end{array}$ & $5 \mu \mathrm{M}$ & - & [47] \\
\hline Film & $\begin{array}{c}\text { Staphylococcus } \\
\text { epidermidis, } \\
\text { Staphylococcus aureus, } \\
\text { Escherichia coli, and } \\
\text { Klebsiella pneumoniae }\end{array}$ & $\begin{array}{l}\text { One sorting cycle to capture, } \\
\text { release a pure bacterial strain, } \\
\text { the dominant role of chemical } \\
\text { recognition }\end{array}$ & $10^{9}$ cells $/ \mathrm{mL}$ & - & [48] \\
\hline Membrane & C-reactive protein & $\begin{array}{l}\text { A specific and cost-effective } \\
\text { approach, catch specific } \\
\text { proteins in complex }\end{array}$ & $0-200 \mu \mathrm{g} / \mathrm{mL}$ & - & [49] \\
\hline Microstructure & Testosterone & $\begin{array}{l}\text { A low-cost, simple, robust, } \\
\text { efficient, less time consuming }\end{array}$ & $0.5-500 \mathrm{nM}$ & $0.5 \mathrm{nM}$ & [50] \\
\hline Fluorescence & Dansyl-L-phenylalanine & $\begin{array}{l}\text { A high sensitivity and } \\
\text { selectivity }\end{array}$ & $1-100 \mu \mathrm{M}$ & $0.5 \mu \mathrm{M}$ & [52] \\
\hline Electrochemical & $\begin{array}{c}\text { Oxytocin } \\
\text { nonapeptide }\end{array}$ & $\begin{array}{l}\text { A high sensitivity and } \\
\text { selectivity }\end{array}$ & $0.06-1 \mathrm{mM}$ & $60 \mu \mathrm{M}$ & [53] \\
\hline Electrochemical & Warfarin sodium & $\begin{array}{c}\text { An accurate, reliable, } \\
\text { interference-free, simple, } \\
\text { low-cost }\end{array}$ & $2 \times 10^{-11}$ to $4 \times 10^{-9} \mathrm{M}$ & $8 \times 10^{-12} \mathrm{M}$ & [54] \\
\hline Electrochemical & Morphine & $\begin{array}{l}\text { A precise and continuous } \\
\text { measurement, compact in size, } \\
\text { consumes fewer samples }\end{array}$ & $0.01-0.2 \mathrm{mM}$ & $0.3 \mu \mathrm{M}$ & [55] \\
\hline Electrochemical & Propofol & $\begin{array}{l}\text { A compact size, high } \\
\text { selectivity, low cost, rapid } \\
\text { response, single-step detection }\end{array}$ & $0.1-30 \mu \mathrm{g} / \mathrm{mL}$ & $0.1 \mu \mathrm{g} / \mathrm{mL}$ & [56] \\
\hline Optical & Propofol & $\begin{array}{l}\text { A disposable, high selectivity, } \\
\text { low cost, rapid response, } \\
\text { single-step detection }\end{array}$ & $0.25-10 \mathrm{ppm}$ & $0.25 \mathrm{ppm}$ & [57] \\
\hline Film & $\begin{array}{l}\text { Adenosine-51- } \\
\text { monophosphate }\end{array}$ & $\begin{array}{l}\text { A detection in real-time, low } \\
\text { concentrations of nucleoside } \\
\text { analogues, good stability }\end{array}$ & 5-600 ppm & $5 \mathrm{ppm}$ & [58] \\
\hline $\begin{array}{c}\text { Magnetic } \\
\text { nanoparticle }\end{array}$ & Bisphenol A & $\begin{array}{l}\text { A highly reproducible } \\
\text { response, good selectivity, } \\
\text { excellent regeneration }\end{array}$ & $10-1000 \mathrm{nM}$ & $6.18 \mathrm{nM}$ & [63] \\
\hline Nanoflowers & $\begin{array}{l}\text { L-glutamic acid and } \\
\text { L-cysteine }\end{array}$ & $\begin{array}{l}\text { A selective, accurate, rapid, } \\
\text { inexpensive, on-site } \\
\text { monitoring }\end{array}$ & $\begin{array}{l}20 \mathrm{pM} \text { to } 1000 \mathrm{nM} \text { and } \\
50 \mathrm{pM} \text { to } 800 \mathrm{nM}\end{array}$ & $9.6 \mathrm{pM}$ and $24 \mathrm{pM}$ & [64] \\
\hline Quantum dot & Phycocyanin & $\begin{array}{l}\text { A robust, facile route to } \\
\text { detection, portability, } \\
\text { disposability, low cost, } \\
\text { user-friendly protocol }\end{array}$ & $10-50 \mathrm{mg} / \mathrm{L}$ & $2 \mathrm{mg} / \mathrm{L}$ & [65] \\
\hline Quantum dot & $\mathrm{Cu}^{2+}$ and $\mathrm{Hg}^{2+}$ ions & $\begin{array}{l}\text { A novel, simple, convenient } \\
\text { analysis, cost-effective, } \\
\text { portable }\end{array}$ & $\begin{array}{c}0.11 \text { to } 58.0 \mu \mathrm{g} / \mathrm{L}\left(\mathrm{Cu}^{2+}\right) \\
\text { and } 0.26-34.0 \mu \mathrm{g} / \mathrm{L} \\
\left(\mathrm{Hg}^{2+}\right)\end{array}$ & $\begin{array}{c}0.035 \mu \mathrm{g} / \mathrm{L}\left(\mathrm{Cu}^{2+}\right) \text { and } \\
0.056 \mu \mathrm{g} / \mathrm{L}\left(\mathrm{Hg}^{2+}\right)\end{array}$ & [66] \\
\hline $\begin{array}{c}\text { Gold } \\
\text { nanoparticle }\end{array}$ & D-glutamic acid & $\begin{array}{l}\text { A high-throughput, sensitive, } \\
\text { specific, multiplex assay }\end{array}$ & $1.2-125.0 \mathrm{nM}$ & $0.2 \mathrm{nM}$ & [67] \\
\hline
\end{tabular}

Funding: This research received no external funding.

Conflicts of Interest: The authors declare no conflict of interest. 


\section{References}

1. Lv, Y.Q.; Tan, T.W.; Svec, F. Molecular imprinting of proteins in polymers attached to the surface of nanomaterials for selective recognition of biomacromolecules. Biotechnol. Adv. 2013, 31, 1172-1186. [CrossRef] [PubMed]

2. Li, L.; Fan, L.; Dai, Y.; Kan, X. Recognition and determination of bovine hemoglobin using a gold electrode modified with gold nanoparticles and molecularly imprinted self-polymerized dopamine. Microchim. Acta 2015, 182, 2477-2483. [CrossRef]

3. Wulff, G.; Sarhan, A. Use of polymers with enzyme analogous structures for the resolution of racemates. Angew. Chem. Int. Ed. 1972, 11, 341.

4. Saylan, Y.; Tamahkar, E.; Denizli, A. Recognition of lysozyme using surface imprinted bacterial cellulose nanofibers. J. Biomat. Sci. Polym. Ed. 2017, 28, 1950-1965. [CrossRef] [PubMed]

5. Safran, V.; Göktürk, I.; Derazshamshir, A.; Yılmaz, F.; Sağlam, N.; Denizli, A. Rapid sensing of $\mathrm{Cu}^{2+}$ in water and biological samples by sensitive molecularly imprinted based plasmonic biosensor. Microchem. J. 2019, 148, 141-150. [CrossRef]

6. Bakhshpour, M.; Yavuz, H.; Denizli, A. Controlled release of mitomycin C from PHEMAH-Cu(II) cryogel membranes. J. Artif. Cell. Nanomed. Biotechnol. 2018, 46, 946-954. [CrossRef] [PubMed]

7. Cabaleiro-Lago, C.; Quinlan-Pluck, F.; Lynch, I.; Lindman, S.; Minogue, A.M.; Thulin, E.; Walsh, D.M.; Dawson, K.A.; Linse, S. Inhibition of amyloid $\beta$ protein fibrillation by polymeric nanoparticles. J. Am. Chem. Soc. 2008, 130, 15437-15443. [CrossRef] [PubMed]

8. Çetin, K.; Denizli, A. 5-Fluorouracil delivery from metal-ion mediated molecularly imprinted cryogel discs. Colloids Surf. B Biointerfaces 2015, 126, 401-406. [CrossRef] [PubMed]

9. Zimmerman, S.C.; Lemcoff, N.G. Synthetic hosts via molecular imprinting-are universal synthetic antibodies realistically possible? Chem. Commun. 2004, 1, 5-14. [CrossRef] [PubMed]

10. Golabi, M.; Kuralay, F.; Jager, E.W.H.; Beni, V.; Turner, A.P.F. Electrochemical bacterial detection using poly(3-aminophenylboronic acid)-based imprinted polymer. Biosens. Bioelectron. 2017, 93, 87-93. [CrossRef] [PubMed]

11. Saylan, Y.; Yılmaz, F.; Özgür, E.; Derazshamshir, A.; Yavuz, H.; Denizli, A. Molecularly imprinting of macromolecules for sensors applications. Sensors 2017, 17, 898. [CrossRef] [PubMed]

12. Mosbach, K. The promise of molecular imprinting. Sci. Am. 2006, 295, 86. [CrossRef] [PubMed]

13. Whitesides, G.M. The origins and the future of microfluidics. Nature 2006, 442, 368-373. [CrossRef] [PubMed]

14. Manz, A.; Harrison, D.J.; Verpoorte, E.M.J.; Fettinger, J.C.; Paulus, A.; Lüdi, H.; Widmer, H.M. Planar chips technology for miniaturization and integration of separation techniques into monitoring systems: Capillary electrophoresis on a chip. J. Chromatog. A 1992, 593, 253-258. [CrossRef]

15. Chin, C.D.; Linder, V.; Sia, S.K. Commercialization of microfluidic point-of-care diagnostic devices. Lab Chip 2012, 12, 2118-2134. [CrossRef] [PubMed]

16. Teh, S.Y.; Lin, R.; Hung, L.H.; Lee, A.P. Droplet microfluidics. Lab Chip 2008, 8, 198-220. [CrossRef] [PubMed]

17. Sia, S.K.; Kricka, L.J. Microfluidics and point-of-care testing. Lab Chip 2008, 8, 1982-1983. [CrossRef] [PubMed]

18. Lifson, M.A.; Ozen, M.O.; Inci, F.; Wang, S.; Inan, H.; Baday, M.; Henrich, T.J.; Demirci, U. Advances in biosensing strategies for HIV-1 detection, diagnosis, and therapeutic monitoring. Adv. Drug Deliv. Rev. 2016, 103, 90-104. [CrossRef] [PubMed]

19. Vera, F.; Zenuto, R.R.; Antenucci, C.D.; Busso, J.M.; Marín, R.H. Validation of a radioimmunoassay for measuring testosterone concentrations in plasma samples of the subterranean rodent Ctenomys talarum: Outstandingly elevated levels in the wild and the effect of captivity. J. Exp. Zool. 2011, 315, 572-583. [CrossRef] [PubMed]

20. Fitzgerald, R.L.; Griffin, T.L.; Herold, D.A. Analysis of testosterone in serum using mass spectrometry. Methods Mol. Biol. 2010, 603, 489-500. [PubMed]

21. Wang, Y.; Gay, G.D.; Botelho, J.C.; Caudill, S.P.; Vesper, H.W. Total testosterone quantitative measurement in serum by LC-MS/MS. Clin. Chim. Acta 2014, 436, 263-267. [CrossRef] [PubMed]

22. Ye, L. Synthetic strategies in molecular imprinting. In Advances in Biochemical Engineering/Biotechnology; Springer: Berlin, Germany, 2015. 
23. Saylan, Y.; Denizli, A. Molecular fingerprints of hemoglobin on a nanofilm chip. Sensors 2018, $18,3016$. [CrossRef] [PubMed]

24. Gast, M.; Sobek, H.; Mizaikoff, B. Advances in imprinting strategies for selective virus recognition a review. Trend Anal. Chem. 2019, 114, 218-232. [CrossRef]

25. Saylan, Y.; Akgönüllü, S.; Yavuz, H.; Ünal, S.; Denizli, A. Molecularly imprinted polymer based sensors for medical applications. Sensors 2019, 19, 1279. [CrossRef] [PubMed]

26. Jia, M.; Zhang, Z.; Li, J.; Ma, X.; Chen, L.; Yang, X. Molecular imprinting technology for microorganism analysis. Trend Anal. Chem. 2018, 106, 190-201. [CrossRef]

27. Yan, H.; Row, K.R. Characteristic and synthetic approach of molecularly imprinted polymer. Int. J. Mol. Sci. 2006, 7, 155-178. [CrossRef]

28. Uzun, L.; Turner, A.P.F. Molecularly-imprinted polymer sensors: Realizing their potential. Biosens. Bioelectron. 2016, 76, 131-144. [CrossRef] [PubMed]

29. Schirhagl, R.; Qian, J.; Dickert, F.L. Immunosensing with artificial antibodies in organic solvents or complex matrices. Sens. Actuators B 2012, 173, 585-590. [CrossRef]

30. Erdem, Ö.; Saylan, Y.; Cihangir, N.; Denizli, A. Molecularly imprinted nanoparticles based plasmonic sensors for real-time Enterococcus faecalis detection. Biosens. Bioelectron. 2019, 126, 608-614. [CrossRef] [PubMed]

31. Middeleer, G.D.; Dubruel, P.; Saeger, S.D. Characterization of MIP and MIP functionalized surfaces: Current state-of-the-art. Trend Anal. Chem. 2016, 76, 71-85. [CrossRef]

32. Justino, C.I.L.; Freitas, A.C.; Pereira, R.; Duarte, A.C.; Rocha Santos, T.A.P. Recent developments in recognition elements for chemical sensors and biosensors. Trend Anal. Chem. 2015, 68, 2-17. [CrossRef]

33. Choi, J.R.; Yong, K.W.; Choi, J.Y.; Cowie, A.C. Progress in molecularly imprinted polymers for biomedical applications. Comb. Chem. High Throughput Screen. 2019, 22, 78-88. [CrossRef] [PubMed]

34. Masliyah, J.H.; Bhattacharjee, S. Electrokinetic and Colloid Transport Phenomena; John Wiley and Sons: Hoboken, NY, USA, 2006.

35. Nobes, D.S.; Abdolrazaghi, M.; Mitra, S.K. Microfluidics and Nanofluidics Handbook, Fabrication, Implementation, and Applications, Image-Based Photonic Techniques for Microfluidics; CRC Press: Boca Raton, FL, USA, 2012.

36. Vasdekis, A.E.; Laporte, G.P.J. Enhancing single molecule imaging in optofluidics and microfluidics. Int. J. Mol. Sci. 2011, 12, 5135-5156. [CrossRef] [PubMed]

37. Mark, D.; Haeberle, S.; Roth, G.; Von Stetten, F.; Zengerle, R. Microfluidic Lab-on-a-Chip Platforms: Requirements, Characteristics and Applications. Microfluidics Based Microsystems; Springer: Berlin, Germany, 2010.

38. Gervais, L.; Rooij, N.D.; Delamarche, E. Microfluidic chips for point-of-care immunodiagnostics. Adv. Mater. 2011, 23, H151-H176. [CrossRef] [PubMed]

39. Zarei, M. Advances in point-of-care technologies for molecular diagnostics. Biosens. Bioelectron. 2017, 98, 494-506. [CrossRef] [PubMed]

40. Schirhagl, R.; Ren, K.N.; Zare, R.N. Surface-Imprinted Polymers in Microfluidic Devices; Springer: Berlin, Germany, 2012.

41. Krupadam, R.J.; Korde, B.A.; Ashokkumar, M.; Kolev, S.D. Novel molecularly imprinted polymeric microspheres for preconcentration and preservation of polycyclic aromatic hydrocarbons from environmental samples. Anal. Bioanal. Chem. 2014, 406, 5313-5321. [CrossRef] [PubMed]

42. Hong, C.C.; Lin, C.C.; Hong, C.L.; Chang, P.H. Enhanced anesthetic propofol biochips by modifying molecularly imprinted nanocavities of biosensors. Biomed. Microdevices 2012, 14, 435-441. [CrossRef] [PubMed]

43. Rico-Yuste, A.; Carrasco, S. Molecularly imprinted polymer-based hybrid materials for the development of optical sensors. Polymers 2019, 11, 1173. [CrossRef] [PubMed]

44. Regan, B.; Boyle, F.; O'Kennedy, R.; Collins, D. Evaluation of molecularly imprinted polymers for point-of-care testing for cardiovascular disease. Sensors 2019, 19, 3485. [CrossRef] [PubMed]

45. Ali, M.; Horikawa, S.; Venkatesh, S.; Saha, J.; Hong, J.W.; Byrne, M.E. Zero-order therapeutic release from imprinted hydrogel contact lenses within in vitro physiological ocular tear flow. J. Control. Release 2007, 124, 154-162. [CrossRef] [PubMed]

46. Shiraki, Y.; Tsuruta, K.; Morimoto, J.; Ohba, J.; Kawamura, A.; Yoshida, R.; Kawano, R.; Uragami, T.; Miyata, T. Preparation of molecule-responsive microsized hydrogels via photopolymerization for smart microchannel microvalves. Macromol. Rapid Commun. 2015, 36, 515-519. [CrossRef] [PubMed] 
47. Takimoto, K.; Takano, E.; Kitayama, Y.; Takeuchi, T. Synthesis of monodispersed submillimeter-sized molecularly imprinted particles selective for human serum albumin using inverse suspension polymerization in water-in-oil emulsion prepared using microfluidics. Langmuir 2015, 31, 4981-4987. [CrossRef] [PubMed]

48. Ren, K.; Zare, R.N. Chemical recognition in cell-imprinted polymers. ACS Nano 2012, 6, 4314-4318. [CrossRef] [PubMed]

49. Hong, C.C.; Chen, C.P.; Horng, C.J.; Chen, S.Y. Point-of-care protein sensing platform based on immuno-like membrane with molecularly-aligned nanocavities. Biosens. Bioelectron. 2013, 50, 425-430. [CrossRef] [PubMed]

50. Kellens, E.; Bové, H.; Vandenryt, T.; Lambrichts, J.; Dekens, J.; Drijkoningen, S.; D’Haen, J.; De Ceuninck, W.; Thoelen, R.; Junkers, T.; et al. Micro-patterned molecularly imprinted polymer structures on functionalized diamond-coated substrates for testosterone detection. Biosens. Bioelectron. 2018, 118, 58-65. [CrossRef] [PubMed]

51. Thaler, M.; Luppa, P.B. Highly sensitive immunodiagnostics at the point of care employing alternative recognition elements and smartphones: Hype, trend, or revolution? Anal. Bioanal. Chem. 2019, 2019, 1-13. [CrossRef] [PubMed]

52. Harz, S.; Schimmelpfennig, M.; Bui, B.T.S.; Marchyk, N.; Haupt, K.; Feller, K.H. Fluorescence optical spectrally resolved sensor based on molecularly imprinted polymers and microfluidics. Eng. Life Sci. 2011, 11, 559-565. [CrossRef]

53. Sharma, P.S.; Iskierko, Z.; Noworyta, K.; Cieplak, M.; Borowicz, P.; Lisowski, W.; D'Souza, F.; Kutner, W. Synthesis and application of a "plastic antibody" in electrochemical microfluidic platform for oxytocin determination. Biosens. Bioelectron. 2018, 100, 251-258. [CrossRef] [PubMed]

54. Liu, J.; Zhang, Y.; Jiang, M.; Tian, L.; Sun, S.; Zhao, N.; Zhao, F.; Li, Y. Electrochemical microfluidic chip based on molecular imprinting technique applied for therapeutic drug monitoring. Biosens. Bioelectron. 2017, 91, 714-720. [CrossRef] [PubMed]

55. Weng, C.H.; Yeh, W.M.; Ho, K.C.; Lee, G.B. A microfluidic system utilizing molecularly imprinted polymer films for amperometric detection of morphine. Sens. Actuator B 2007, 121, 576-582. [CrossRef]

56. Hong, C.C.; Lin, C.C.; Hong, C.L.; Lin, Z.X.; Chung, M.H.; Hsieh, P.W. Handheld analyzer with on-chip molecularly-imprinted biosensors for electrical detection of propofol in plasma samples. Biosens. Bioelectron. 2016, 86, 623-629. [CrossRef] [PubMed]

57. Hong, C.C.; Chang, P.H.; Lin, C.C.; Hong, C.L. A disposable microfluidic biochip with on-chip molecularly imprinted biosensors for optical detection of anesthetic propofol. Biosens. Bioelectron. 2010, 25, 2058-2064. [CrossRef] [PubMed]

58. Dejous, C.; Hallil, H.; Raimbault, V.; Lachaud, J.; Plano, B.; Delépée, R.; Favetta, P.; Agrofoglio, L.; Rebière, D. Love acoustic wave-based devices and molecularly-imprinted polymers as versatile sensors for electronic nose or tongue for cancer monitoring. Sensors 2016, 16, 915. [CrossRef] [PubMed]

59. Cheng, C.M.; Martinez, A.W.; Gong, J.; Mace, C.R.; Phillips, S.T.; Carrilho, E.; Mirica, K.A.; Whitesides, G.M. Paper-based ELISA. Angew. Chem. Int. Ed. 2010, 49, 4771-4774. [CrossRef] [PubMed]

60. Liu, H.; Crooks, R.M. Three-dimensional paper microfluidic devices assembled using the principles of origami. J. Am. Chem. Soc. 2011, 133, 17564-17566. [CrossRef] [PubMed]

61. Tian, T.; Wei, X.; Jia, S.; Zhang, R.; Li, J.; Zhu, Z.; Zhang, H.; Ma, Y.; Lin, Z.; Yang, C.J. Integration of target responsive hydrogel with cascaded enzymatic reactions and microfluidic paper-based analytic devices (PADs) for point-of-care testing (POCT). Biosens. Bioelectron. 2016, 77, 537-542. [CrossRef] [PubMed]

62. Lu, Y.; Shi, W.; Jiang, L.; Qin, J.; Lin, B. Rapid prototyping of paper-based microfluidics with wax for low-cost, portable bioassay. Electrophoresis 2009, 30, 1497-1500. [CrossRef] [PubMed]

63. Kong, Q.; Wang, Y.; Zhang, L.; Ge, S.; Yu, J. A novel microfluidic paper-based colorimetric sensor based on molecularly imprinted polymer membranes for highly selective and sensitive detection of bisphenol A. Sens. Actuators B 2017, 243, 130-136. [CrossRef]

64. Kong, Q.; Wang, Y.; Zhang, L.; Xu, C.; Yu, J. Highly sensitive microfluidic paper-based photoelectrochemical sensing platform based on reversible photo-oxidation products and morphology preferable multi-plate $\mathrm{ZnO}$ nanoflowers. Biosens. Bioelectron. 2018, 110, 58-64. [CrossRef] [PubMed]

65. Li, B.; Zhang, Z.; Qi, J.; Zhou, N.; Qin, S.; Choo, J.; Chen, L. Quantum dot-based molecularly imprinted polymers on three-dimensional origami paper microfluidic chip for fluorescence detection of phycocyanin. ACS Sens. 2017, 2, 243-250. [CrossRef] [PubMed] 
66. Qi, J.; Li, B.; Wang, X.; Zhang, Z.; Wang, Z.; Han, J.; Chen, L. Three-dimensional paper-based microfluidic chip device for multiplexed fluorescence detection of $\mathrm{Cu}^{2+}$ and $\mathrm{Hg}^{2+}$ ions based on ion imprinting technology. Sens. Actuators B 2017, 251, 224-233. [CrossRef]

67. Ge, L.; Wang, S.; Yu, J.; Li, N.; Ge, S.; Yan, M. Molecularly imprinted polymer grafted porous Au-paper electrode for a microfluidic electro-analytical origami device. Adv. Funct. Mater. 2013, 23, 3115-3123. [CrossRef]

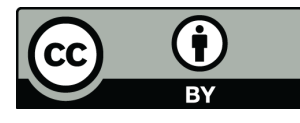

(C) 2019 by the authors. Licensee MDPI, Basel, Switzerland. This article is an open access article distributed under the terms and conditions of the Creative Commons Attribution (CC BY) license (http://creativecommons.org/licenses/by/4.0/). 